\title{
Historein
}

Vol $11(2011)$

Politics and History



How Much Does Historical Truth Still Matter?

Marina Cattaruzza

doi: $10.12681 /$ historein.139

Copyright $\odot$ 2012, Marina Cattaruzza

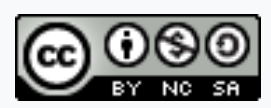

This work is licensed under a Creative Commons Attribution-NonCommercialShareAlike 4.0.

\section{Pierre Nora}

Jörn Rüsen

Wolfgang Benz

Luigi Cajani

Antoon De Baets

To cite this article:

Cattaruzza, M. (2012). How Much Does Historical Truth Still Matter?. Historein, 11, 49-58.

https://doi.org/10.12681/historein.139 


\section{1}

In February 2007 the prestigious Italian publisher II Mulino released Italian-Israeli historian Ariel Toaff's book Pasque di sangue: Ebrei d'Europa e omicidi rituali (Bloody Easter: European Jews and Ritual Murders). The book received a glowing, full-page accolade from the Italian historian Sergio Luzzatto in the Corriere della Sera shortly before its release. It was praised as a gesture of "incredible intellectual courage" and as a brilliant historical achievement.'

Luzzatto, nevertheless, remained alone in his praise. In the days that followed the publication of the book and, as they admitted, after a merely superficial reading, prominent experts on medieval, modern and Jewish history such as Diego Quaglioni, Adriano Prosperi, Giacomo Todeschini and Marina Cafiero commented on it in the pages of the most important (and other less important) daily and weekly Italian newspapers. ${ }^{2}$ Across the board the book was condemned in no uncertain terms. How can the vehement tone that marked the criticism of Bloody Easter be explained?

Well, in his book Ariel Toaff questioned a deeply rooted, central assumption in medieval anti-Semitism and anti-Judaism studies, namely that the admissions by Jewish defendants to having practised blood rituals were, without exception, made at the suggestion of Inquisition judges and elicited by means of torture. Having been subject to torture, the unfortunate victims were prepared to admit anything their judges wanted to hear. Toaff challenged this assump-

\section{How Much Does}

\section{Historical Truth}

Still Matter?
Marina Cattaruzza

Berne University 
tion. On the basis of an impressive reconstruction of various rituals of Christian and Jewish heretical sects in which the prohibited substance of "blood" played a central role, he claimed that among marginalised, sectarian groups of Ashkenazi Jews, the blood of Christians (usually acquired for a fee directly from impoverished but very much living Christians) was used for Easter rites intended to damn the Christian oppressors.

In a second article in the Corriere della Sera, Sergio Luzzatto argued on Toaff's behalf, saying that a historian should not consider certain statements as a priori wrong just because they were made under torture, especially if such statements are verified in other sources. ${ }^{3}$ But the reaction to Toaff's arguments was so vehement that the author himself withdrew the book after a week. Among others, the author's father, Elio Toaff, former head rabbi of Rome's Jewish congregation, distanced himself publicly from his son's argument. Ariel Toaff's employer, the University of Bar Ilan in Tel Aviv, suffered the withdrawal of several million dollars in research money from private donors and the academic senate considered having their controversial colleague dismissed. This threat nevertheless has remained unfulfilled. ${ }^{4}$

In the meantime Toaff has republished the volume, after reformulating some of his arguments more precisely so as to avoid misunderstandings. His central thesis remains the same: in heretic Jewish sects the blood of Christians (sold to them illegally by people in need of money) was used in rituals held to damn the Christian oppressor. It cannot be excluded, so Toaff argues, that in a small number of cases the blood used was that of Christian victims. He is nevertheless not in a position to say anything about the frequency of such cases. On the whole, this hypothesis of actual ritual murder is presented much more carefully in the new edition and the focus is shifted more to the therapeutic and ritual use of human blood in both Christian and Jewish cultures during the Middle Ages and the Renaissance.

In the introduction to the new edition, Toaff writes: "The central theses presented in the first edition remain unchanged. I present them again here in this new edition and accept the responsibility for doing so. ${ }^{\mathrm{5}}$

In his afterword, in which he summarises the criticism of his opponents, Toaff articulates an important position on which he believes the vehemence of the reaction to the first edition was based, namely that his book challenges a dyed-in-the-wool stereotype: this consists in the assumption that through history all Jews have been without exceptions passive and resigned victims. ${ }^{6}$ Toaff's theses in fact challenge the assumption that victims are qua definition completely innocent. It is at this point that Toaff's case, which affects the Ashkenazi Jewish communities of the twelfth to the fourteenth centuries, touches on the central focus of this article, in which I want to examine to what degree the currently widespread attribution of victim status to groups of people in the past can be a hindrance to an unbiased historical analysis. In other words, to what degree do historians tend to adopt in their historical narrative what I want to call here a "moral narrative"? 
The relationship of historical writing to the "truth" is by definition an ambivalent one.7 Historical practice is located in the site of tension between a critical examination of the sources and a narrative reconstruction, in which the historian fills the documentary gaps and interstices with his own imagination. That the claim to the truthfulness of history can only be limited and that the science of history is unable to recreate bygone reality was already discussed by Johann Gustav Droysen in 1857 in his lecture on "Historik", in which he concluded that we are only able to recognise those elements of the past that are still present in one way or the other in the present. ${ }^{8}$ Of course, the discussion of the relationship of the science of history to the past has evolved ever since and a whole palette of positions on the existence or nonexistence of a past reality beyond its historical reconstruction has emerged. Most historians involved in empirical research agree even today that there is a relationship between a historical narrative and a past reality, while this relationship is denied for the most part by philosophers of history and epistemologists. As even Richard Rorty, one of the most prominent antirealists, commented several years ago, albeit as an aside at a conference, "What harm is done when historians rely on the commonsense assumption that there is a historical reality out there to 'get right'?"9 In other words, the answer to the question of the existence of a historical reality does little to resolve the problem of the "truth postulate" or, in more modest terms, the "objectivity postulate".

The historical sciences can hardly do away with any normative claim to truth or objectivity, without calling into question their right to exist as such. But the claim to "historical truth" is always seen in a specific context and implemented for achieving specific goals. In a cursory examination of the Historical Abstracts database for example, since the beginning of the 1990s the phrase "historical truth" is used - as was to be expected - most often in connection with the revision of obsolete historical narratives in countries in transition from socialism or in connection with issues of "justice", "reconciliation", the repatriation of goods and compensation for injustices suffered, that is, the definition of truth relates to phenomena or aims which lay outside the proper field of historical research.

Since "historical truth" is always dependent on the context and perspective, it is, in my opinion, inevitable that the contemporary "moralisation of the past", as studied among others by Pascal Bruckner and Heinrich Lübbe, ${ }^{10}$ also affects historiographical practice, namely in the sense that elements of the prevailing moral discourse are absorbed, with little or no reflection, into the historical narrative and without them being sufficiently documented in the sources. The following considerations are therefore to be understood as a contribution to the critique of historical writing in the era of a hegemonic moralising discourse. The point is not to try to solve the problem of the moral interpretation of historical phenomena, " but much more modestly to examine how historical narratives are affected by existing practices of victimisation and self-victimisation. In past times, historical writing took place mostly in interaction with national or ideological discourses; ${ }^{12}$ under such conditions objectivity was, of course, subject to distortions too. These distortions have so far been studied in the past more frequently than has been the case for the "moral narrative", which is taken for granted today. 
The ambivalence of many historiographical categories is something historians need to recognise, so that they can better cope with the inevitable limits to their own normative ideals. ${ }^{13}$ But this certainly does not mean refraining from having any such ideals at all. As the late German historian Thomas Nipperdey once said, "That, which we are able to achieve, is not a completely objective history but a more objective history."14

The category of "understanding", which implies that the historian does his utmost to gain the mindset of the historical subjects living in the period he is dealing with, has been repeatedly challenged because of its "epistemological relativism". ${ }^{15}$ The aspiration to "historical understanding", namely, is challenged by the fact that historians will never be able to fully bridge the gap between themselves and people acting in the past.

The moral relativism implied by "understanding" has also been challenged, albeit less frequently, by Geoffrey Barraclough, for instance, who has accused historicism of "amorality". ${ }^{16}$ This accusation cannot be ignored outright. In his/her attempt to determine the motivation of historical actors for their handling in the past, the historian cannot avoid developing at least a partial justification for their acts. It is notable that avowed historicists like Thomas Nipperdey and Wolfgang Mommsen were well aware of such moral dilemmas and called for the suspension of the need to "understand" in some extreme cases such as the Holocaust (or the Armenian genocide or the Stalinist terror) ${ }^{17}$ This is obviously not a methodologically satisfactory solution, since these extreme cases must first be recognised as such and defined as "radically evil", above and beyond "normal evil". In his important study on the Reserve Police Battalion 101, Christopher Browning made the following statement on the ambiguity of understanding: "Explaining is not excusing; understanding is not forgiving. Not trying to understand the perpetrators in human terms would make impossible not only this study but any history of Holocaust perpetrators that sought to go beyond one-dimensional caricature."18

It is nevertheless true, as the political scientist Paolo Portinaro found, that the Holocaust is also the source of the crisis of historicism. This is not only because it is the "extreme case" par excellence but because this "civilisation breach"19 also radically questioned the idea of human progress. Besides, in comparisons between National Socialism and Communism it is often stressed that Communist crimes (as, for example, the elimination of "Kulaks") were committed to achieve rational aims: consequently they were "understandable" and therefore incomparable with the national socialist ones. ${ }^{20}$ Besides, we are still lacking a systematical and comparative analysis of the specific aspects of the Holocaust which are not comparable with other genocides or mass murders. ${ }^{21}$ In taking note of this, I am not arguing against the singular character of the Holocaust even compared with other genocides..$^{22}$ My point is rather that historians need a sharper analytical distinction between the elements which made up the unique character of the Holocaust and the comparable ones. In a 2006 essay I stated: 'The 'uniqueness' of Shoah is ... based on the simultaneous occurrence of genocidal elements (and first of all of genocidal will) in an unprecedented radical form. However, the single murderous elements are recognisable in other cases of genocide as well."23 
The German "Historikerstreit" (historians' quarrel) of 1986 also has at its core the (moral and epistemological) Janus-headed nature of understanding. The scandal of Ernst Nolte's argument was that, in his reasoning, the attempt to make Hitler's deeds and primarily the murder of the European Jews "understandable" became recognisable. The most often quoted passage from the article "Die Vergangenheit, die nicht vergehen will" (The past what won't go away) is, in fact, as follows:

But nevertheless, the following question must be admissible, indeed it appears inevitable: did the Nazis, did Hitler, perform an "Asian" act perhaps only because they considered themselves and their own as potential or actual victims of such an "Asian" act? Was not the "gulag archipelago" prior to Auschwitz? Was not the "class genocide" of the Bolsheviks the logical and factual predecessor of the Nazi "racial genocide"? Are Hitler's most secret acts not also to be explained in terms of his inability to forget [the Chinese torture of] the "rat cage"? Did Auschwitz perhaps have its origins in a past that would not go away?24

The historical unacceptability of these statements has been discussed innumerable times. It was, however, rarely pointed out that the emotional response that Nolte's article met with was based on the fear of, even for one second, identifying with Hitler's (admittedly paranoid) motives; it would have made the radically evil in some way "understandable", shortening our distance from it.

With his ambiguous and unclear formulations, Nolte had only himself to blame for the scandal that followed the publication of his theses. However, another protagonist in this historical dispute, Andreas Hillgruber, is an entirely different case. Hillgruber, a traditional historian of foreign policy and undoubtedly one of the best experts on the Second World War, had published shortly before the outbreak of the controversy surrounding Nolte's theses a booklet entitled Zweierlei Untergang: Die Zerschlagung des Deutschen Reiches und das Ende des europäischen Judentums (Double downfall: the dismantling of the German Reich and the end of European Jewry) ${ }^{25}$ Therein Hillgruber discussed in two separate and quite disparate chapters: first, the expulsion of the German population from the eastern territories and, second, the murder of the European Jews by Nazi Germany during the Second World War. Hillgruber was lumped together with Ernst Nolte and thus drawn into the Historikerstreit. The massive attacks that he had to suffer can nevertheless only be explained in part as a result of his awkward correlation of two themes or his untimely sympathies for the German civilian population of the eastern territories. In his reconstruction of how the resettlement of millions of Germans came about, Hillgruber included not only Hitler's war crimes but also Allied foreign policy goals (including those of the Soviet Union) and the policies of the Polish and Czechoslovak governments-in-exile. On the one hand, Hillgruber focused his argument on the category of the intentionality of historical subjects, which is today considered rather unfashionable. On the other hand, in his reconstruction of events he questioned the generally accepted causal link between "collective guilt" and "collective punishment"; his argument was that although the crimes of the German occupying forces in the Second World War were singular in their atrocity, they were not the main or only reason for the expulsion of the German population. In doing so, Hillgruber challenged a narrative that even today is very difficult to analyse critically, namely the historical narrative according to which the mass violence against the German population in the last phase of the Second World War and their expulsion from the Eastern territories are attributed exclusively to atrocities perpetrated previously by the Germans. 
Even today, when the state of research on the mass resettlements is much more advanced than in the mid-1980s, it is difficult to challenge explicitly such "moral coherence", in spite of the fact that there is so little evidence for it in the historical documentation. ${ }^{26}$ In other cases beyond the one being discussed here (the more or less violent expulsion of the German population from parts of eastern central Europe), the category of "reaction" to the opposite party's crimes is often used more or less consciously to justify atrocities against them, the "reactive" crimes of course being classified as less serious than those that provoked reaction. Such an assessment, which frequently flows into historical narratives as well, does not often stand the test of close analysis. Apparently, not only in the public sphere but also in historical discourse is it difficult to differentiate between the moral condemnation of crimes and the cognitive reconstruction of historical processes. In other words, it is not easy to resist the temptation to attribute to historical events a certain sense of justice, to use justice (inappropriately) as a historical category.

\section{4}

Since the fall of the Berlin Wall, a wave of new compensation negotiations for the various victims of National Socialism in the formerly communist countries has appeared. For the first time since the Second World War, victims of National Socialism who found themselves behind the "Iron Curtain" were included in such considerations by the Federal Republic of Germany. ${ }^{27}$ The opening of such proceedings, which were essentially a partial retribution for the victims from these countries commensurate with the payments made by the FRG to victims living in Israel and Western European countries between the 1950s and the 1970s, naturally contributed to reinforce the victim's perspective when considering past events. Historians like Peter Novick, Omer Bartov and Tony Judt ${ }^{28}$ have stressed, each with their own accent, that the figure of the "freedom fighter", which in the immediate postwar period played an essential role in social normalisation and stabilisation processes in both Eastern and Western Europe and in the USA as well, ${ }^{29}$ has been replaced by the figure of the "victim", with all its archetypal characteristics of passivity, innocence and purity.

Such a transformation is related to a broader conversion of values which occurred in Europe in the period after the Second World War and which led to an emphasis on civil and pacifist virtues as a reaction to the atrocities of both world conflicts. ${ }^{30}$ History writing today also tends to emphasise the representation of the suffering of the victims in place of the historical reconstruction of decision-making processes and structural conditions that could contribute to understanding this suffering. Such an emphasis inevitably leads to historical processes being interpreted in the simple dichotomy of victims vs. perpetrators. The Holocaust specialist Omer Bartov warned of the consequences of such a simplification a few years ago and demanded that historians not only refuse this simple model but also pointed out the effects that the use of such simplifications had produced in the past. ${ }^{31}$

Be that as it may, victimisation and self-victimisation today enjoys a great deal of popularity in public discourse, as demonstrated in how the past is being dealt with in the former communist countries. In a newer contribution on the subject, entitled "How to Deal with the Past", Anatoly M. Khazanov and Stanley G. Payne define the following trends: 
The status of victimhood was clearly recognised immediately after World War II, with respect to the victims of the Axis, but its meaning was changed and expanded later in the twentieth century, as the new ideology of political correctness replaced the class struggle with its own categories of victimisers and victims. Meanwhile, quite apart from the "victimist ideology" of political correctness, a constant revision of national narratives has taken place, with an ever-growing concern to achieve victimhood status, even on the part of countries that historically were primarily victimisers. Whenever possible, historical perpetration is downplayed, while, conversely, new claims of victimisation of quite a different order acquire growing importance. ${ }^{32}$

In Poland, the publication of a study by the Polish-American historian Jan Gross on a bloody pogrom perpetrated by Poles in the town of Jedwabne in 1941 led to violent attacks, threats and lawsuits against the author; ${ }^{33}$ this is just a further example of how difficult it is for a national community to confront a deeply ingrained victim identity and to admit the darker side of its own history.

The purpose of these reflexions has been, as I have already mentioned, to point out some of the potential problems that historical research may encounter in facing the dominant victim-andperpetrator dichotomy of public discourse. I hope that the examples have made my point clear; in the following I will briefly recapitulate my theories, concluding that:

First, historical research has always been practised in a context marked by nonscientific, nonscholarly factors. This has been the case with national histories, the history of the labour movement or the history of various discriminated groups. But the affirmation of counternarratives or complementary narratives was easier in those cases than in the current public victimisation discourse. This latter discourse claims a higher and more universal moral legitimacy. This makes it all the easier for historical analyses that question even partial aspects of this construct to be accused of moral unworthiness.

Second, the high moral authority attributed to the victim's perspective creates a situation in which other values, in their limited scope perfectly respectable and legitimate, such as the specific morality of the quest for knowledge, are put at risk. To use Max Weber's words, in the "battle of gods" (that is, of competing values) the winner may be decided before the debate begins. Criteria specific to the historical sciences, such as the ideal of a nuanced reconstruction of singular historic processes, or a sceptical and relativist attitude towards received knowledge, or the willingness to reconsider and reinterpret given facts, may all be massively affected.

Finally, the higher good involved in the creation of a common value system intended to contribute to communication in a globalised world ${ }^{34}$ could lead to "historic truth" being subordinated completely to other "higher" values, thereby losing its status as a desirable scholarly ideal. Therefore, I return to my initial question to which I admittedly have no answer: "How much does historical truth still matter?" 


\section{NOTES}

1 Sergio Luzzatto, "Quelle Pasque di Sangue: Il fondamentalismo ebraico nelle tenebre del Medioevo", Corriere della Sera, 6 Feb 2007.

2 "Gli storici demoliscono il libro di Ariel Toaff che dà credito alla calunnia antisemita degli omicidi rituali", Informazione Corretta, 9 Feb 2007, www.informazionecorretta.it/main.php?mediald=999920\&sez=120 \&id=19382, accessed 2 Feb 2011; Anna Esposito and Diego Quaglioni, “Pasque di sangue, le due facce del pregiudizio", Corriere della Sera, 11 Feb 2007.

3 Sergio Luzzatto, "La storia divisa”, Corriere della Sera, 26 Feb 2007.

4 Davide Frattini, “L'Università difende Ariel Toaff”, Corriere della Sera, 14 Feb 2007.

5 Ariel Toaff, Pasque di sangue: Ebrei d'Europa e omicidi rituali, Bologna: Il Mulino, 2008 (1st ed. 2007), 6.

6 Ibid., 366, 371, 390, 392, 393.

7 Cf. on this point the provocative article by Hayden White, "Historical Emplotment and the Problem of Truth", in Saul Friedlander (ed.), Probing the Limits of Representation: Nazism and the 'Final Solution', Cambridge: Harvard UP, 1992, 37-53. See also “Truth”, in Alun Munslow, The Routledge Companion to Historical Studies, London: Routledge, 2006, 236-238.

8 Johann Gustav Droysen, Historik, vol. 1: Rekonstruktion der ersten vollständigen Fassung der Vorlesungen (1857): Grundriß der Historik in der ersten handschriftlichen (1857/1858) und in der letzten gedruckten Fassung (1882), ed. Peter Leyh, Stuttgart: Fromann-Holzboog, 1977, 8, 422. Several decades later, Benedetto Croce stated in late Hegelian manner that every form of history is contemporary history. Cf. Benedetto Croce, Teoria e storia della storiografia, Milan: Adelphi, 1989 (1st ed. 1915), 13-17.

9 Quotation in Thomas L. Haskell, "Objectivity: Perspective as Problem and Solution”, History and Theory 43, (2004), 341-359, here 347.

10 Hermann Lübbe, "Ich entschuldige mich": Das neue politische Bußritual, Berlin: Siedler 2001, particularly 90-95; Pascal Bruckner, La tyrannie de la pénitence: essai sur le masochisme occidental, Paris: Bernard Grasset, 2006.

11 For a criticism of the "ethic relativism" in American historical writing, see, for example, Peter Novick, "That Noble Dream": Objectivity Question and the American Historical Profession, Cambridge: Cambridge UP, 1988, 282-288.

12 See, for example, Stefan Berger and Chris Lorenz (eds), The Contested Nation: Ethnicity, Class, Religion and Gender in National Histories, Basingstoke: Palgrave Macmillan, 2008; Lutz Raphael, Geschichtswissenschaft im Zeitalter der Extreme: Theorien, Methoden, Tendenzen von 1900 bis zur Gegenwart, Munich: Beck 2003.

13 Cf. "Objectivity", in Munslow, The Routledge Companion to Historical Studies, 191-194.

14 Thomas Nipperdey, "Kann Geschichte objektiv sein?", Geschichte in Wissenschaft und Unterricht 30 (1979), 329-342, here 339.

15 "Historicism", in Munslow, The Routledge Companion to Historical Studies, 141.

16 Geoffrey Barraclough, "The Historian in a Changing World", in Hans Meyerhoff (ed.), The Philosophy of History in Our Time, New York: Anchor, 1959, 28-35. On the issue of the ethical relativism of historicism, see also Arnaldo Momigliano, "Historicism Revisited", Mededelingen der Koninklijke Nederlandse 
Akademie van Wetenschappen, Afd. Letterkunde Nieuwe Reeks 37/3 (1974), 63-70, particularly 7-8. On "historical understanding", see Thomas Nipperdey, "Historismus und Historismuskritik heute. Bemerkungen zur Diskussion", in Idem, Gesellschaft, Kultur, Theorie, Göttingen: Vandenhoeck \& Ruprecht, 1976, 59-73, here 71-72.

17 Nipperdey, “Kann Geschichte objektiv sein?” 335; Haskell, Objectivity: Perspective as Problem and Solution, 350-351.

18 Christopher Browning, Ordinary Men. Reserve Police Battalion 101 and the Final Solution in Poland, New York: Harper, 1993, xx.

19 Dan Diner (ed.), Zivilisationsbruch: Denken nach Auschwitz, Frankfurt am Main: Fischer, 1988.

20 Dan Diner, “Zivilisationsbruch': la frattura di civiltà come epistemologia della Shoah”, in Marina Cattaruzza, Marcello Flores, Simon Levis Sullam and Enzo Traverso (eds), Storia della Shoah: La crisi dell'Europa, lo sterminio degli ebrei e la memoria del XX secolo, vol. 1, Turin: UTET, 2005, 15-37; Enzo Traverso, "Comparare la Shoah: questioni aperte”, Ibid., vol. 3, 2006, 166-203; Omer Bartov, "Elusive Enemies", in Idem, Mirrors of Destruction: War, Genocide, and Modern Identity, Oxford: Oxford UP, 2000, 91-142, particularly 140-141.

21 Saul Friedländer, Mass Murder and German Society in the Third Reich: Interpretations and Dilemmas, London: Royal Holloway, 2001 (= Hayes Robinson Lecture Series, vol. 5); Marina Cattaruzza, "Il ruolo degli 'uomini comuni' nello sterminio degli ebrei europei", Storia della Storiografia 30 (1996), 141-150. Harald Schmid has pointed astutely to the aporie between the theorem of Holocaust singularity and the contemporary universalising discourse, in which numerous genocides or mass murders are described as "Holocausts". Cf. Harald Schmid, "Europäisierung des Auschwitzgedenkens? Zum Aufstieg des 27. Januar 1945 als 'Holocaustgedenktag' in Europa", Jan Eckel and Claudia Moisel (eds), Universalisierung des Holocausts? Erinnerungskultur und Geschichtspolitik in internationaler Perspektive, Göttingen: Wallstein, 2008, 174-202, here 177.

22 Marina Cattaruzza, "The Historiography of the Shoah: An Attempt at a Bibliographical Synthesis", Totalitarismus und Demokratie: Zeitschrift für Internationale Diktatur- und Freiheitsforschung 3/2 (2006), 285-321, particularly 317-321.

23 Ibid., 320.

24 Ernst Nolte, "Vergangenheit, die nicht vergehen will: Eine Rede, die geschrieben aber nicht gehalten werden konnte", in Rudolf Augstein et al. (eds), "Historikerstreit": Die Dokumentation der Kontroverse um die Einzigartigkeit der nationalsozialistischen Judenvernichtung, Munich: Piper, 1987, 39-47.

25 Andreas Hillgruber, Zweierlei Untergang: die Zerschlagung des Deutschen Reiches und das Ende des europäischen Judentums, Berlin: Prophyläen, 1986.

26 Marina Cattaruzza, “Endstation Vertreibung: Minderheitenfrage und Zwangsmigrationen in Ostmitteleuropa, 1919-1949", Journal of Modern European History 6/1 (2008), 5-29, here 7-11.

27 Constantin Goschler and Philipp Ther (eds), Raub und Restitution: "Arisierung" und Rückerstattung des jüdischen Eigentums in Europa, Frankfurt am Main: Fischer 2003.

28 Tony Judt, “The Past is Another Country: Myth and Memory in Postwar Europe”, in István Deák, Jan Tomasz Gross and Tony Judt (eds), The Politics of Retribution in Europe: World War II and Its Aftermath, Princeton: Princeton UP, 2000, 293-323, particularly 298-305; Bartov, “Elusive Enemies”.

29 See Peter Novick, The Holocaust in American Life, Boston: Houghton Mifflin, 1999; Judt, "The Past is 
Another Country", in Pieter Lagrou, The Legacy of Nazi Occupation: Patriotic Memory and National Recovery in Western Europe, 1945-1965, Cambridge: Cambridge UP, 2001.

30 James J. Sheehan, Where have all the Soldiers gone? The Transformation of Modern Europe, New York: Houghton Mifflin, 2008, particularly 183-273.

31 Bartov, “Elusive enemies", 137-142.

32 Anatoly M. Khazanov and Stanley G. Payne, "How to Deal with the Past?", Totalitarian Movements and Political Religions 9/2-3 (2008), 411-431, here 422.

33 Jan T. Gross, Neighbors: The Destruction of the Jewish Community of Jedwabne, Poland, Princeton: Princeton UP, 2001; Ruth Henning (ed.), Die "Jedwabne-Debatte" in polnischen Zeitungen und Zeitschtiften: Dokumentation, Potsdam: Deutsch-Polnische Gesellschaft Brandenburg, 2001; Laurence Weinbaum, The Struggle for Memory in Poland: Auschwitz, Jedwabne and Beyond, Jerusalem: Institute of the World Jewish Congress, 2002; Antony Polonsky (ed.), The Neighbors Respond: The Controvery over the Jedwabne Massacre in Poland, Princeton: Princeton UP, 2004.

34 Thomas Maissen, "Nationalgeschichten als internationales Thema: Die Aktualität von Genozid-Vorwürfen und Entschuldigungen, Neue Zürcher Zeitung, 27 Mar 2007. 